\title{
Reducing the phosphorus effluent load from a paddy-field district through cyclic irrigation
}

\section{$\operatorname{AUTHOR}(\mathrm{S}):$}

Hama, Takehide; Aoki, Takeru; Osuga, Katsuyuki; Sugiyama, Sho; Iwasaki, Daichi

\section{CITATION:}

Hama, Takehide ...[et al]. Reducing the phosphorus effluent load from a paddy-field district through cyclic irrigation. Ecological Engineering 2013, 54: 107-115

\section{ISSUE DATE:}

2013-05

URL:

http://hdl.handle.net/2433/178674

\section{RIGHT:}

(C) 2013 Elsevier B.V.; This is not the published version. Please cite only the published version.; この論文は出版社版でありません。引用の際に は出版社版をご確認ご利用ください。 


\section{Reducing the phosphorus effluent load from a paddy-field district through cyclic irrigation}

Takehide Hama $^{a}$, Takeru Aoki ${ }^{b}$, Katsuyuki Osuga ${ }^{c}$, Sho Sugiyama ${ }^{a}$, Daichi Iwasaki ${ }^{a}$

${ }^{a}$ Graduate School of Agriculture, Kyoto University, Kitashirakawa Oiwake-cho, Sakyo Ward, Kyoto 606-8502, Japan

${ }^{b}$ Tokyo Gas Co., Ltd., 1-5-20 Kaigan, Minato Ward, Tokyo 105-8527, Japan

${ }^{c}$ Shiga Prefectural Government, 4-1-1 Kyo-machi, Otsu City, Shiga 520-8577, Japan

*Corresponding author. Graduate School of Agriculture, Kyoto University,

Kitashirakawa Oiwake-cho, Sakyo Ward, Kyoto 606-8502, Japan.

Tel.: +81-75-753-6176; fax: +81-75-753-6476.

E-mail address: hama@kais.kyoto-u.ac.jp (T. Hama). 


\section{ABBREVIATIONS}

P phosphorus

TP total phosphorus

$\mathrm{PO}_{4}-\mathrm{P} \quad$ phosphate phosphorus

CI cyclic irrigation

LWI lake-water irrigation

Non-I non-irrigation

C phosphorus concentration, $\mathrm{mg} \cdot \mathrm{L}^{-1}$

$Q \quad$ volumetric flow rate, $\mathrm{mm} \cdot \mathrm{d}^{-1}$

$C_{\text {in }} \quad$ phosphorus concentration of influent water, $\mathrm{mg} \cdot \mathrm{L}^{-1}$

$C_{\text {out }} \quad$ phosphorus concentration of effluent water, $\mathrm{mg} \cdot \mathrm{L}^{-1}$

$Q_{\text {in }} \quad$ volumetric flow rate of influent water, $\mathrm{mm} \cdot \mathrm{d}^{-1}$

$Q_{\text {out }} \quad$ volumetric flow rate of effluent water, $\mathrm{mm} \cdot \mathrm{d}^{-1}$

$L_{\text {net }} \quad$ net phosphorus export, $\mathrm{kg} \cdot \mathrm{ha}^{-1} \cdot \mathrm{d}^{-1}$

$\alpha_{\mathrm{CI}} \quad$ cyclic irrigation ratio

$\alpha_{\mathrm{SW}} \quad$ surplus irrigation water ratio

$\chi \quad$ concentration ratio

$\chi_{\mathrm{TP}} \quad$ concentration ratio of total phosphorus

$\beta \quad$ neutral effect curve for the net phosphorus export 


\section{ABSTRACT}

Phosphorus (P) effluent load discharged from paddy fields has a substantial impact on water quality in downstream areas. We evaluated the effectiveness of cyclic irrigation, in which drainage water is reused for irrigation purposes, in reducing the P load from a paddy-field district neighboring Lake Biwa, Japan. We measured temporal variations in the $\mathrm{P}$ concentration in drainage water and estimated the $\mathrm{P}$ mass balance for the study district for three consecutive years (2007-2009). A simple model was developed to characterize the hydrological structure and effects of cyclic irrigation using three parameters: the ratio of the $\mathrm{P}$ concentration in drainage water to that in irrigation water, the degree to which drainage water is reused, and the ratio of surplus irrigation water to the total amount of irrigation water. The total annual exports of $\mathrm{P}$ were $2.62-3.13 \mathrm{~kg} \cdot \mathrm{ha}^{-}$ ${ }^{1}$. Phosphorus exports during the cyclic irrigation periods (April-June) were $0.27-0.63$ $\mathrm{kg} \cdot \mathrm{ha}^{-1}$ (period average rate $=3.7-8.8 \mathrm{~g} \cdot \mathrm{ha}^{-1} \cdot \mathrm{d}^{-1}$ ), lower than those during the lake water irrigation periods (July-August) of $0.82-1.66 \mathrm{~kg} \cdot \mathrm{ha}^{-1}\left(8.9-18.0 \mathrm{~g} \cdot \mathrm{ha}^{-1} \cdot \mathrm{d}^{-1}\right)$. Phosphorus export was lowest during the cyclic irrigation period, consistent with the small amounts of discharged drainage water. Our results suggest that cyclic irrigation is an effective district-scale method for reducing effluent P loads. Reuse of drainage water and efficient use of irrigation water are important in reducing the $\mathrm{P}$ load from the district.

Keywords: Phosphorus, Cyclic irrigation, Paddy field, Water reuse 


\section{Introduction}

Removal of pollutants such as suspended solids, organic matter, and nutrients from non-point sources is an important issue in managing water quality in downstream areas. Phosphorus $(\mathrm{P})$ is a nutrient that when present in high concentrations causes water quality problems in many aquatic systems (Correll, 1998; Sharpley, 1993). Rice-paddy fields, which use large amount of irrigation water, are among the major non-point sources (Bouman et al., 2007; Krupa et al., 2011; Yoshinaga et al., 2007). Suspended solid and nutrient loads in paddy-field effluent have substantial impacts on downstream ecosystems - notably, eutrophication, algal blooms, and freshwater red tides — that can be reduced through environmentally friendly farming practices. Various management practices have been carried out for reducing nutrient loads from paddy fields. Field-scale practices include reducing the amount of chemical fertilizer used by applying slow-release fertilizer (e.g., Choi and Nelson, 1996; Fan and Li, 2010).

Cyclic irrigation, in which drainage water is reused for irrigation, is considered an effective water management technique for reducing pollutants from paddy fields (Feng et al., 2005, 2004; Hama et al. 2011, 2010; Takeda and Fukushima, 2006, 2004; Takeda et al., 1997)). Using this technique, more water is retained in the paddy fields, reducing the volume of run-off carrying potential pollutants. In addition, the water that does leave the fields is partially purified, because the longer hydraulic retention time allows for increased absorption of nutrients in the fields, reducing the amount released as pollutants (Takeda and Fukushima, 2006; Takeda et al., 1997). The effectiveness of cyclic irrigation is directly proportional to the amount of water that is reused (Kaneki, 
2003) and to the intensity (Hitomi et al., 2006; Shiratani et al., 2004). However, because cyclic irrigation requires using large quantities of freshwater to reduce the risks associated with pathogens and heavy metals (Zulu et al., 1996), there is a limit to the intensity used in many paddy-field districts that capture industrial or domestic wastewater from upstream areas. Accordingly, little is known about the effectiveness of high-intensity cyclic irrigation in reducing nutrient effluent loads from paddy-field districts.

Our objectives in this study were to understand the characteristics of P effluent loads in a paddy-field district implementing high-intensity cyclic irrigation, and to evaluate the effectiveness of that technique in reducing these loads. We focused our analysis on a paddy-field district neighboring Lake Biwa, Japan, over three consecutive years (2007-2009).

\section{Materials and methods}

\subsection{Study site}

Our study site was a low-lying paddy-field district located on the southeastern edge of Lake Biwa $\left(35^{\circ} 05^{\prime} \mathrm{N}, 135^{\circ} 56^{\prime} \mathrm{E}\right.$, Fig. 1(a)). Lake Biwa $\left(670 \mathrm{~km}^{2}\right)$ is the largest lake in Japan and the most important water resource for about 14 million people in the Kinki region, including Osaka and Kyoto Prefectures. The mean annual temperature and rainfall are $15^{\circ} \mathrm{C}$ and $1550 \mathrm{~mm}$. The district covers an area of about $1.5 \mathrm{~km}^{2}$, with more 
than $90 \%$ of that area comprised of paddy fields. Rotation crops, specifically wheat (from November to June) and soybeans (from June to November), are grown on about one-third of the area on a three-year cycle.

Within the district, a drainage and irrigation system is employed in which the canals for each process are separate (Fig.1(b)). Further, no industrial or domestic wastewater from outside the district flows into the drainage or irrigation canals. The drainage portion of the system contains one main and 14 lateral canals and floodgates at both ends of the main canal. In addition, each paddy field has an outlet at the surface (surface water drainage) and an underground pipeline with an outlet (tile drainage). These outlets are connected to the adjacent lateral drainage canals. When rice is cultivated, the surface outlet is shuttered with a board and the outlet of the tile drainage is capped to flood the fields. In contrast, the outlets of the fields that are fallow or under crop rotation cultivation are opened to enhance drainage of rainfall. Runoff water or tile drainage water from the fields during rainfall events flows into the main drainage canal via each lateral drainage canal and then is discharged through the floodgates. During our study period, the northern floodgate was closed, forcing the outflow of all drainage water through the southern floodgate. Two pump stations are located at the northern and southern ends of the main drainage canal with maximum capacities of approximately $2.5 \times 10^{3}$ and $0.2 \times 10^{3} \mathrm{~m}^{3} \cdot \mathrm{h}^{-1}$, respectively. The northern pump station has two water inlets that connect to Lake Biwa and to the main drainage canal, whereas the southern pump station has a single water inlet that connects only to the main drainage canal. The inlets of the northern pump were switched according to irrigation method. Because there are no water sources other than Lake Biwa, the maximum amount of available water for 
irrigation depends solely on the capacity of these pumps.

In the district, two irrigation techniques were used at specific times of year during the four-month irrigation period (Table 1). Cyclic irrigation was employed for the first half of the season (the cyclic irrigation period), where recycled drainage water was used to flood the paddy fields. When the drainage water level fell by evapotranspiration and the lake-side inlet of the northern pump was closed, water flowed from the lake to the drainage canal through the floodgate. Lake water irrigation was then used for the second half of the irrigation period (the lake water irrigation period), when cool water was needed for maximum rice quality. Under lake water irrigation, irrigation water was pumped directly from Lake Biwa through the northern pump. A 10-day midsummer drainage season separated the use of these irrigation techniques. The pumps were operated every day except on rainy days during the cyclic irrigation period, whereas operation was intermittent during the lake water irrigation period. The period from the end of the irrigation period to the beginning of the next irrigation period is referred to as the non-irrigation period.

About $30 \mathrm{~kg} \mathrm{P} \cdot \mathrm{ha}^{-1}$ of chemical fertilizer is normally applied to rice in late April before transplanting (Hama et al., 2012). In wheat cultivation, about $80 \mathrm{~kg} \mathrm{P} \cdot \mathrm{ha}^{-1}$ is applied to the fields as base fertilizer in November and $30 \mathrm{~kg} \mathrm{P} \cdot \mathrm{ha}^{-1}$ is added in December and in February. Phosphorus fertilizer is not applied to soybeans.

\subsection{Water quality and hydrological measurements}

Drainage water in the district was sampled daily at noon at the southern end of the main 
drainage canal (St. 1; Fig. 1(b)) for three consecutive years (from April 2007 to April 2010) using a programmable automatic water sampler (3700 Sampler; Teledyne Isco Inc., Lincoln, NE, USA). A small plastic tank was placed near the northern pump station to collect rainfall. The drainage water and rainfall samples were collected during weekly field visits. In addition, drainage water, irrigation water, and water in the lake were sampled at weekly intervals at St. 1, St. 2 (pump outlet), and St. 3 (near and outside of the northern floodgate), respectively, during field visits. The manually sampled water was analyzed for total $\mathrm{P}(\mathrm{TP})$ and phosphate $\mathrm{P}\left(\mathrm{PO}_{4}-\mathrm{P}\right)$. Drainage water samples from the automatic sampler and rainfall water samples were analyzed for TP. Total P was determined by potassium persulfate digestion followed by the molybdenum blue method (Murphy and Riley, 1962); $\mathrm{PO}_{4}-\mathrm{P}$ was also determined by this method after filtration through a $1-\mu \mathrm{m}$ filter.

Meteorological instruments for measuring rainfall, air temperature, wind velocity, relative humidity, and solar radiation were installed in an open area at the southern pump station (Fig.1(b)). Evapotranspiration during the irrigation period was estimated by the Penman method (Penman, 1948) using data measured at the southern pump station and the crop coefficient value for rice (Sakuratani and Horie, 1985). Evapotranspiration during the non-irrigation period was estimated from the water balance for the district. We measured the flow rates of discharged drainage water (lake water irrigation period) and of inflowing lake water (cyclic irrigation period) using a flow meter (2150 Area Velocity Flow Module; Teledyne Isco, Inc.) installed at the southern end of the main drainage canal. We estimated the volume of pumped water by multiplying the amount of time the pumps were in operation by their capacities. We did 
not measure subsurface percolation from the district but assumed it to be negligible because the district is low-lying and close to the lake with high groundwater levels.

We calculated the water balance over a fixed portion of each irrigation period to compare values across years, although the lengths of the irrigation periods varied (Table 2); water balance for the cyclic irrigation period was measured from April 20 to June 30, for the lake water irrigation period from July 1 to September 30, and for the non-irrigation period from October 1 to April 19 of the following year. Daily inputs and exports of $\mathrm{P}$ were estimated by multiplying $\mathrm{P}$ concentrations by flow volumes.

\subsection{Simple model for assessing the effect of the irrigation system on effluent load}

In this study, we determined the net $\mathrm{P}$ export as a mean of assessing the effects of irrigation techniques on reducing effluent loads in the district, where the net $\mathrm{P}$ export is defined as $\mathrm{P}$ export $-\mathrm{P}$ input. Because $\mathrm{P}$ load is dependent on both the $\mathrm{P}$ concentration and the volumetric flow rate, we defined the net P export, $L_{\mathrm{net}}\left(\mathrm{kg} \cdot \mathrm{ha}^{-1} \cdot \mathrm{d}^{-1}\right)$, as:

$$
L_{\text {net }}=C_{\text {out }} \times Q_{\text {out }}-C_{\text {in }} \times Q_{\text {in }}
$$

where $C$ is the $\mathrm{P}$ concentration $\left(\mathrm{mg} \cdot \mathrm{L}^{-1}\right)$ and $Q$ the volumetric flow rate $\left(\mathrm{mm} \cdot \mathrm{d}^{-1}\right)$, and the subscripts out and in refer to outflow from and inflow into the district, respectively. In this case, $C_{\text {out }}$ is the $\mathrm{P}$ concentration of the drainage water; $Q_{\text {out }}$, the amount of drainage water discharged from the district; $C_{\mathrm{in}}$, the $\mathrm{P}$ concentration of the lake water or irrigation water under lake water irrigation; and $Q_{\mathrm{in}}$, the amount of lake water intake. 
$L_{\text {net }}>0$ indicates that the district is adding to the P load downstream (net export), while $L_{\text {net }}<0$ indicates that the district is reducing it (net retention). In a previous study (Durisch-Kaiser et al., 2011), a similar concept to the net load was used to estimate the rate of nutrient transformation or production (referred to as the reaction rate) in lakes. They calculated the reaction rate as $R=\left(C_{\text {out }}-C_{\text {in }}\right) \times Q / A$, where $R$ represents the reaction rate $\left(\mathrm{mmol} \cdot \mathrm{m}^{-2} \cdot \mathrm{d}^{-1}\right), C$ the concentrations at the inflow and outflow of a lake, $Q$ the average flow $\left(\mathrm{L} \cdot \mathrm{d}^{-1}\right)$, and $A$ the total lake surface area $\left(\mathrm{m}^{2}\right)$. Positive $R$ and negative $R$ indicated production or transformation, respectively, of nutrients or carbon species (Durisch-Kaiser et al., 2011).

Considering the neutral condition in which $L_{\text {net }}=0$, Eq. 1 reduces to:

$$
C_{\text {out }} / C_{\text {in }}=Q_{\text {in }} / Q_{\text {out }}
$$

where $C_{\text {out }} / C_{\text {in }}$ is defined as the concentration ratio, $\chi$. If $\chi>1$, there is internal load of nutrients from the sediment (Portielje and Van der Molen, 1999). In our study, $\chi>1$ suggests that the $\mathrm{P}$ concentration increases through internal loading from the main drainage canal (Fig. 1), whereas $\chi<1$ indicates a decrease in P concentration.

We were able to determine the values of each variable needed to calculate net $\mathrm{P}$ export through a conceptual understanding of the relationships among water flows in the system (Fig. 2). Because this system uses a closed irrigation canal, we determined the volume of irrigation water $\left(Q_{\mathrm{p}}\right)$ directly from the volume of water that is passed through the pump. The inflow of water from the lake $\left(Q_{\text {in }}\right)$ can then be calculated by multiplying the volume of the irrigation water by the proportion of water that is not 
reused through cyclic irrigation:

$$
Q_{\text {in }}=\left(1-\alpha_{\mathrm{CI}}\right) Q_{\mathrm{p}}
$$

where $\alpha_{C I}$ is the cyclic irrigation ratio, defined as the ratio of the amount of reused water to the total amount of irrigation water (Hama et al., 2010).

The amount of drainage water that is discharged from the district $\left(Q_{\text {out }}\right)$ can be calculated as a function of the percentage of water that is considered surplus irrigation water and not used in the paddy fields $\left(\alpha_{\mathrm{SW}}\right)$ and the percentage of water that is reused for cyclic irrigation:

$$
Q_{\text {out }}=\left(\alpha_{\mathrm{SW}}-\alpha_{\mathrm{CI}}\right) Q_{\mathrm{p}}
$$

This model does not consider temporary deficits in the inflow of water, which can lead to a decrease in the amount of drainage water stored in the drainage canal. As noted previously, when the amount of drainage water in the canal falls (alternatively, when $\alpha_{\mathrm{SW}}<\alpha_{\mathrm{CI}}$ in Eq. 4), water must be brought in from the lake. In this case the net $\mathrm{P}$ export can be described as a negative net export:

$$
L_{\text {net }}=-\left(1-\alpha_{\mathrm{SW}}\right) C_{\text {in }} \times Q_{\text {in }}<0 \text { for any } \alpha_{\mathrm{CI}}
$$

and cyclic irrigation may always show a net retention effect.

From the above-mentioned relationships between water flows in our model 
(Fig. 2), we can replace the variables on the right side of Eq. 2 with the relationships established in Eqs. 3 and 4:

$$
\beta=\left(1-\alpha_{\mathrm{CI}}\right) /\left(\alpha_{\mathrm{SW}}-\alpha_{\mathrm{CI}}\right)
$$

where $\beta$ varies as a function of both $\alpha_{\mathrm{CI}}$ and $\alpha_{\mathrm{SW}}$. Using this information, we can show the effect of irrigation on $L_{\text {net }}$ for a given $\alpha_{\text {SW }}$ value (Fig. 3). The irrigation system has a net export effect when the concentration ratio of TP $\left(\chi_{\mathrm{TP}}\right)$ is above the $\beta$ curve and a net retention effect when $\chi_{\mathrm{TP}}$ is below that curve. In addition, when $\chi_{\mathrm{TP}}<1$, irrigation for any $\alpha_{\mathrm{CI}}$ may show a net retention effect of irrigation because $\beta \geq 1$ for any combination of $\alpha_{\mathrm{CI}}$ and $\alpha_{\mathrm{SW}}$. This simple model allows us to determine the effect of cyclic irrigation on the effluent load from the paddy district under various cyclic irrigation intensities $\left(\alpha_{\mathrm{CI}}\right)$.

\section{Results}

\subsection{Water balance}

Figure 4 shows the daily variations in rainfall and water discharged from the district.

Drainage water was mainly discharged in association with rainfall events during cyclic irrigation periods, whereas drainage water of $10-15 \mathrm{~mm} \cdot \mathrm{d}^{-1}$ was released even on clear days during the lake water irrigation periods. Discharge of water during lake water 
irrigation was due to surplus irrigation water and lateral water flow from the paddy fields to the drainage canals. The amount of lateral water flow was estimated at about 3$5 \mathrm{~mm} \cdot \mathrm{d}^{-1}$, based on previous research (Hama et al., 2010, 2011). This indicates that surplus irrigation water is the main source of drainage water discharged during lake water irrigation. During the non-irrigation period, water was only discharged during rainfall events because no irrigation water was taken in.

Water balances for the district for the three investigation periods are shown in Table 2. Annual rainfall ranged from $1332 \mathrm{~mm}$ in 2009 to $1633 \mathrm{~mm}$ in 2007. Weather conditions in the investigation years were considered normal because annual rainfall was within the mean \pm standard deviation $(1549 \pm 291 \mathrm{~mm})$ for three decades of data (1980-2009; Japan Meteorological Agency, 2010). The amount of water discharged was lowest during the cyclic irrigation period, likely due to reuse of drainage water. The amount of irrigation water, equivalent to pumped water estimated from operation of the pumps, during the cyclic irrigation period was $965 \mathrm{~mm}$ in 2007, $964 \mathrm{~mm}$ in 2008, and $1046 \mathrm{~mm}$ in 2009 . These amounts of irrigation water under cyclic irrigation represent the lake water intake that would have to be pumped from Lake Biwa if lake water irrigation had been used instead of cyclic irrigation. The difference between the amount of irrigation water and the lake water intake represents the amount of water reused under cyclic irrigation. Thus, the amount of reused water was $792 \mathrm{~mm}$ in $2007,864 \mathrm{~mm}$ in 2008 , and $878 \mathrm{~mm}$ in 2009 . The cyclic irrigation ratio is the proportion of drainage water reused to irrigation water and is an indicator of the intensity of cycling of irrigation water (Hama et al., 2010). The cyclic irrigation ratio in the study district was 82,90 , and $84 \%$ in 2007,2008 and 2009. 
The highest amount of discharged water was measured during the lake water irrigation periods in 2007 and 2008, even though rainfall was not the highest in these investigation years. This large amount of discharged water was due to surplus irrigation water not used for the paddy fields (Fig. 4). During lake water irrigation, the amount of lake water intake (Table 2) is approximately the same as the total irrigation water (reused water at the southern pump was less than $7 \%$ of total irrigation water) and was 677,648 , and $605 \mathrm{~mm}$ in 2007, 2008, and 2009, respectively. The amount of irrigation water during the lake water irrigation period was lower than that during the cyclic irrigation period, suggesting that the amount of lake water intake during the lake water irrigation periods was reduced by intermittent operation of the pumps; more water would have been discharged if the pumps had been operated every day.

\subsection{Phosphorus concentrations}

Figure 5 shows daily variations in TP concentrations in drainage water. Phosphorus concentrations were high in early May, coinciding with the transplanting season for rice seedlings. These high TP concentrations resulted from runoff from the paddy fields after soil puddling, which is a practice to soften the soil and level the surface for transplanting and flooding. High TP concentrations were also observed on rainy days. Total P concentrations on clear days during the irrigation period were $0.10-0.20 \mathrm{mg} \cdot \mathrm{L}^{-1}$. Table 3 lists the mean concentrations of TP in drainage water sampled daily during the various irrigation management phases. The TP concentration tended to be highest during the non-irrigation period. However, rainfall may have had a large influence on 
variations in the TP concentrations, particularly during non-irrigation periods when the rice crop had already been harvested in the paddy fields and the P-rich paddy soil was susceptible to erosion.

Mean concentrations of TP and $\mathrm{PO}_{4}-\mathrm{P}$ in drainage water and irrigation water during the various irrigation management phases are shown in Table 4. Pairs of data for drainage water and irrigation water sampled on the same days were used for these calculations, although we collected some drainage water samples without irrigation water samples on clear days during the lake-water irrigation period in which the pumps were intermittently operated. The sampled P concentrations in drainage water and irrigation water are believed to be representative for the irrigation methods because drainage water and irrigation water were sampled on the same day, when the pumps were operating. The percentage of $\mathrm{PO}_{4}-\mathrm{P}$ of TP in the drainage water was low (14-26\%), suggesting that $\mathrm{P}$ in the drainage water is discharged mainly as particulates. The mean TP concentration in drainage water during the cyclic irrigation period tended to be higher than that during the lake water irrigation period. The mean TP concentration in irrigation water during the cyclic irrigation period was also significantly higher than that during the lake water irrigation period (all data, $p<0.05$ ). Phosphorus concentrations in irrigation water during lake water irrigation represent $\mathrm{P}$ concentrations in the lake water, which were low.

\subsection{Phosphorus inputs and exports}

The inputs of TP in rainfall and lake water and the exports of TP in discharged water 
during the various phases of irrigation management are shown in Table 5. The total annual exports of $\mathrm{P}$ were $2.62-3.13 \mathrm{~kg} \cdot \mathrm{ha}^{-1}$. The $\mathrm{P}$ exports during the cyclic irrigation periods (72 days) were $0.27-0.63 \mathrm{~kg} \cdot \mathrm{ha}^{-1}\left(3.7-8.8 \mathrm{~g} \cdot \mathrm{ha}^{-1} \cdot \mathrm{d}^{-1}\right)$, whereas those during the lake water irrigation periods (92 days) were $0.82-1.66 \mathrm{~kg} \cdot \mathrm{ha}^{-1}\left(8.9-18.0 \mathrm{~g} \cdot \mathrm{ha}^{-1} \cdot \mathrm{d}^{-1}\right)$. Phosphorus exports were lowest during the cyclic irrigation periods, consistent with the small amounts of water discharged (Table 2). Phosphorus exports during the lake water irrigation periods were higher than during the cyclic irrigation periods, although TP concentrations in the drainage water were lower than those during cyclic irrigation (Table 4). Some of the P exports during the lake water irrigation period were associated with discharge of surplus irrigation water on clear days (Fig. 4). During the non-irrigation periods, P exports were highest in 2008 and 2009. Phosphorus exports during the non-irrigation periods accounted for 27,48 , and $54 \%$ of the total annual export of $\mathrm{P}$ in 2007, 2008, and 2009, respectively.

\subsection{Model of net phosphorus exports under cyclic irrigation}

Figure 6 shows the results of application of the model to irrigation management. The TP concentration ratios $\left(\chi_{\mathrm{TP}}\right)$ were $1.5-10.0$ during lake water irrigation $\left(\alpha_{\mathrm{CI}}=0.0-0.16\right)$ and 2.2-16.5 during cyclic irrigation $\left(\alpha_{\mathrm{CI}}=0.62-1.0\right)$, with $\chi_{\mathrm{TP}}$ typically higher during cyclic irrigation than during lake water irrigation. The $\chi_{\mathrm{TP}}$ in 2007, compared to 2008 and 2009, was lower due to higher TP concentration in the lake water $(0.05 \pm 0.02$ $\mathrm{mg} \cdot \mathrm{L}^{-1}$, Table 4). These results indicate that TP concentrations in water flowing through the drainage canals increase under both irrigation methods because $\chi_{\mathrm{TP}}>1\left(\chi_{\mathrm{TP}}>\beta_{1}\right.$ in 
Fig. 6) regardless of $\alpha_{\mathrm{CI}}$ for all of our measurements.

Figure 6 also suggests that use of cyclic irrigation with high $\alpha_{\mathrm{CI}}$ has a net retention effect for any $\chi_{\mathrm{TP}}$, whereas use of lake water irrigation has a net export effect when the surplus irrigation water ratio $\left(\alpha_{\mathrm{SW}}\right)$ is large (e.g., $\left.\alpha_{\mathrm{SW}} \geq 0.7\right)$. An order of magnitude estimate of the amount of surplus irrigation water can be determined based on the difference between the amount of irrigation water and evapotranspiration (Table 2) by assuming that the amount of water supplied to the paddy fields is comparable to that of evapotranspiration. The amount of surplus irrigation water was estimated as approximately $790-860 \mathrm{~mm}$ during cyclic irrigation periods and $200-350 \mathrm{~mm}$ during lake water irrigation periods. Accordingly, $\alpha_{\mathrm{SW}}$ (surplus irrigation water / irrigation water) was estimated as $0.71-0.73$ during the cyclic irrigation and $0.31-0.48$ during the lake water irrigation. Lower $\alpha_{\mathrm{SW}}$ during the lake water irrigation periods may be due to intermittent operation of the pumps. Therefore, lake water irrigation in the district may lead to net $\mathrm{P}$ export, even when $\alpha_{\mathrm{SW}}$ is low during the irrigation period. In contrast, cyclic irrigation has a net retention effect on P for any possible $\alpha_{\mathrm{Sw}}$.

\section{Discussion}

It can be concluded that cyclic irrigation decreases the P effluent load compared to typical irrigation, such as lake water irrigation, in which the drainage water is not reused. The beneficial effect of cyclic irrigation results from reducing the outflow of discharged water. However, cyclic irrigation does not necessarily decrease P concentrations in 
drainage water. During the cyclic irrigation period, mean TP concentrations in irrigation water tended to be higher than in drainage water (Table 4). We sampled drainage water at St.1 (Fig. 1) near the southern floodgate, which acted as the inlet for lake water under cyclic irrigation, whereas we sampled irrigation water at St. 2 near the outlet of the water pumped from the northern end of the drainage canal. Sampling point St. 1 is therefore upstream of St. 2 during cyclic irrigation. This suggests that water flowing through the main drainage canal is contaminated with $\mathrm{P}$, which may derive from the bottom sediment, because P concentrations in the drainage water sampled near the floodgate may be diluted by inflow of lake water with low P concentrations. On the other hand, during lake water irrigation, mean TP concentrations in the irrigation water were lower than in the drainage water (Table 4). This result also supports the potential for $\mathrm{P}$ contamination from the drainage canal, because the drainage water is not reused and irrigation water is pumped directly from the lake (St. 2, Fig. 1) to the floodgate (St. 1) through the canals.

We previously confirmed that the suspended solids concentration in the drainage water was higher under cyclic irrigation than under lake water irrigation, and that drainage water intake under cyclic irrigation caused a higher flow velocity in the drainage canal, which caused sediment resuspension (Hama et al., 2010). Additionally, a previous study of the paddy plots demonstrated that runoff from the plots occurred primarily during rainfall events (Hama et al., 2011), suggesting that P may not be supplied to the drainage canal from the fields on clear days. Resuspension of sediment containing $\mathrm{P}$ is, therefore, regarded as the primary cause of higher $\mathrm{P}$ concentrations under cyclic irrigation. Takeda and Fukushima (2004) reported that P concentrations in 
discharged water decreased as the water flowed downstream, and that precipitation of sediment containing $\mathrm{P}$ was an important factor in reducing $\mathrm{P}$ concentrations in a cyclic irrigation system. The difference between their and our results may relate to whether there is regular dredging of the sediment, which allows the stream bed to store fresh sediment transported from the paddy fields. In our study district, dredging of the sediments in the main drainage canal, other than in the southern area (about $100 \mathrm{~m}$ long), has not been conducted since 2004 when the canal was constructed. Therefore, we infer that the capacity of the drainage canal for storing new sediment has been reduced, and fresh sediment can be stored temporarily but is easily resuspended by water flow under cyclic irrigation. The sediments in the drainage canal generally have a large $\mathrm{P}$ buffering capacity and act as source or sink of P for the overlying water by P release from or absorption to the sediments (e.g., Banaszuk et al., 2011; Froelich, 1988; House et al., 1995; Kröger et al., 2008; Reddy et al., 1996; Sallade and Sims, 1997; Smith et al., 2005). Our results suggest that the sediment in the drainage canal in the studied paddy-field district can act as a source of $\mathrm{P}$ and is an important hydro-chemical link between field-scale and district-scale P exports (Barlow et al., 2003).

Figure 6 confirms that in the studied system, the beneficial effect of cyclic irrigation is mainly due to a decrease in discharged water volume rather than a decrease in P concentration. The arrows in Fig. 6 conceptually describe the effects of cyclic irrigation compared to lake water irrigation, as well as changes in these effects on the net $\mathrm{P}$ export if $\alpha_{\mathrm{CI}}$ is increased. If the $\mathrm{P}$ concentration increases by implementing cyclic irrigation, both $\alpha_{\mathrm{CI}}$ and $\chi_{\mathrm{TP}}$ increase, shown in our results by arrow i. Fig. 6 indicates both the present results of these irrigation methods and potential approaches to reducing 
net $\mathrm{P}$ export: reducing the $\mathrm{P}$ concentration in the drainage water (decrease in $\chi_{\mathrm{TP}}$ ), increasing the amount of reused drainage water (increase in $\alpha_{\mathrm{CI}}$ ), and efficient use of irrigation water such as implementation of intermittent irrigation (horizontal left shift in the $\beta$ curve associated with a decrease in $\left.\alpha_{\mathrm{SW}}\right)$.

To reduce $\chi_{T P}$, dredging the sediment may be effective because removal of sediment containing P reduces the possibility of $\mathrm{P}$ release from the sediment and increases the capacity of the drainage canal for storing fresh sediment. However, Smith et al. (2006) pointed out that dredging left behind a smaller percentage of fine particles and organic matter in the sediment, which decreased the P buffering capacity of the sediment as a $\mathrm{P}$ sink. In addition, land use affects $\mathrm{P}$ content in the sediment, and high $\mathrm{P}$ input to the drainage canal decreases the $\mathrm{P}$ buffering capacity of the sediment (Ahiablame et al., 2011; Haggard et al., 2007).

As shown in Eq. 4, the two quantitative parameters $\alpha_{\mathrm{CI}}$ and $\alpha_{\mathrm{SW}}$ are closely linked. For example, the quantity of discharged water resulting from lake water irrigation assuming $\alpha_{\mathrm{CI}}=0.0$ and $\alpha_{\mathrm{SW}}=0.3$ would be equivalent to that of cyclic irrigation with $\alpha_{\mathrm{CI}}=0.7$ and $\alpha_{\mathrm{SW}}=1.0$. These irrigation management approaches would both have a net export effect (Fig. 6), although $\alpha_{\mathrm{SW}}=0.3$ (only $30 \%$ of irrigation water becomes water waste) and $\alpha_{C I}=0.7$ (70\% of irrigation water is supplied by reuse water) are highly improved values compared to the usual cases (e.g., Kaneki, 2003; Zulu et al., 1996). Both parameters, therefore, should be simultaneously improved to reduce discharged water and net $\mathrm{P}$ export.

The amount of water discharged during lake water irrigation (Fig. 4) suggests that irrigation water can be one of the primary driving forces of water flow and effluent 
load in a paddy-field district equipped with an extensive irrigation and drainage system. Cyclic irrigation interrupts and reduces this driving force through reuse (Eq. 3). The efficiency of water quality conservation measures is generally evaluated based on reducing either P loads $\left(\mathrm{kg} \cdot \mathrm{ha}^{-1}\right)$ or concentrations $\left(\mathrm{mg} \cdot \mathrm{L}^{-1}\right)$ (Kleinman et al., 2011). Thus, cyclic irrigation is considered an effective district-scale measure for reducing $\mathrm{P}$ loads, although it may not necessarily reduce $\mathrm{P}$ concentrations in water.

However, one important remaining issue is reduction of the P loads during rainfall events, which is another major driving force. Water discharged during rainfall events canceled out the beneficial effect of cyclic irrigation, resulting in positive net $\mathrm{P}$ exports from the district during the cyclic irrigation periods in all investigation years (Table 5). To reduce the $\mathrm{P}$ load, improvement of management practices at the field scale is important because cyclic irrigation is not available during rainfall events; other district-scale practices such as construction of a large treatment wetland or regular dredging of the drainage canals are impractical.

In the district, $\mathrm{P}$ export during the non-irrigation periods accounted for approximately half of the annual total export of $\mathrm{P}$ (Table 5). Therefore, reduction of the P load during non-irrigation periods is also important. Previous studies have also suggested that reductions in the effluent load of suspended solids or P from watersheds during the non-growing season or winter and spring season provide opportunities for further reduction in the load (Ball Coelho et al., 2012; McDowell and Wilcock, 2004; Richards et al., 2008). Phosphorus load during the non-irrigation period can be reduced by closing the outlets and enhancing the water storage capacity of the field, which may reduce effluent with particulate (soil-bound) $\mathrm{P}$ in surface runoff water and dissolved $\mathrm{P}$ in 
tile drainage water (Ball Coelho et al., 2012; Heathwaite and Dils, 2000; Simard et al., 2000; Uusitalo et al., 2000). However, this measure is not available for the crop rotation fields because the outlets in those fields must be open to prevent crop damage caused by waterlogging. Our previous study suggests that rotation farming in low-lying districts is a significant non-point source and the development of best management practices for rotation crops are required (Hama et al., 2012).

In this study, we did not evaluate another effect of cyclic irrigation, i.e., returning $\mathrm{P}$ to the paddy fields. Total $\mathrm{P}$ concentrations in irrigation water under cyclic irrigation are high (Table 4), and P returned by cyclic irrigation water may be available for uptake by the rice, although $\mathrm{P}$ in irrigation water exists mainly in the particulate form. If the potential for particulate P to serve as fertilizer can be quantitatively clarified, farmers could reduce their use of $\mathrm{P}$ fertilizer. This may in turn decrease $\mathrm{P}$ in the soil and in effluent from the paddy fields via overflow or tile drainage flow during rainfall events. Further studies are required to evaluate the fertilization potential of particulate $\mathrm{P}$ in cyclic irrigation water.

\section{Conclusions}

We determined that use of cyclic irrigation techniques, in which drainage water is reused, can effectively reduce P effluent loads from paddy-field districts. The reduction of $\mathrm{P}$ load in cyclic irrigation is mainly due to a decrease in the amount of water discharged from the district. Reuse of drainage water may not decrease and may even 
increase $\mathrm{P}$ concentrations in drainage and irrigation water, which have initially low $\mathrm{P}$ concentrations.

The hydrological structure and effects of cyclic irrigation systems can be characterized using three parameters: the concentration ratio $(\chi)$, the cyclic irrigation ratio $\left(\alpha_{\mathrm{CI}}\right)$, and the surplus irrigation water ratio $\left(\alpha_{\mathrm{SW}}\right)$. This simple model may be applied to assess the effects of irrigation techniques on nutrient or suspended solids effluent loads in other paddy-field districts. We found that when $\chi_{\mathrm{TP}}>1$ under cyclic or lake water irrigation, the sediment in the drainage canal in the paddy-field district may act as a source of $\mathrm{P} . \alpha_{\mathrm{CI}}$ and $\alpha_{\mathrm{SW}}$, which are linked together, are quantitative parameters and strong indicators of the efficiency of water use in the district. The effects of cyclic irrigation can be determined by using a high value for $\alpha_{\text {CI. }}$.

However, reduction of $\mathrm{P}$ loads during rainfall events remains a major issue. Discharged water during rainfall events canceled out the beneficial effects of cyclic irrigation, resulting in positive net $\mathrm{P}$ exports from the district during the cyclic irrigation period. In particular, $\mathrm{P}$ exports during the non-irrigation periods associated with rainfall were large and accounted for about half of the annual $\mathrm{P}$ exports in the district. Improvement of water management practices during the non-irrigation period is required to further reduce $\mathrm{P}$ loads from paddy-field districts.

\section{Acknowledgments}

We thank the Konohama Agricultural Union and the Shiga Prefecture Office for providing access to paddy plots for our investigation and for providing daily reports on 
water management and farming activities in the paddy fields. This study was partly funded by a Grant-in-Aid for Scientific Research from the Japan Society for the Promotion of Science.

\section{REFERENCES}

Ahiablame, L.M., Chaubey, I., Smith D.R., Engel, B.A., 2011. Effect of tile effluent on nutrient concentration and retention efficiency in agricultural drainage ditches. Agric. Water Manage. 97, 1271-1279.

Ball Coelho, B., Murray, R., Lapen, D., Topp, E., Bruin, A., 2012. Phosphorus and sediment loading to surface water from liquid swine manure application under different drainage and tillage practices. Agric. Water Manage. 104, 51-61.

Banaszuk, P., Wysocka-Czubszek, A., Komacki, A.K., 2011. Internal eutrophication of restored peatland stream: the role of bed sediments. Ecol. Eng. 37, 260-268.

Barlow, K., Nash, D., Turral, H., Grayson, R., 2003. Phosphorus uptake and release in surface drains. Agric. Water Manage. 63, 109-123.

Bouman, B.A.M., Humphreys, E., Tuong, T.P., Barker, R., 2007. Rice and water. Adv. Agron. 92, 187-237.

Choi, J. M., Nelson, P. V., 1996. Developing a slow-release nitrogen fertilizer from organic sources: II. Using poultry feathers. J. Am. Soc. Hort. Sci. 121 (4), 634-638.

Correll, D.L., 1998. The role of phosphorus in the eutrophication of receiving waters: a review. J. Environ. Qual. 27, 261-266.

Durisch-Kaiser, E., Doberer, A., Reutimann, J., Ravel, A., Balan, S., Wehrli, B., 2011. 
Organic matter governs N and P balance in Danube Delta lakes. Aquat. Sci. 73, 21-33.

Fan, X.H., Li, Y.C., 2010. Nitrogen release from slow-release fertilizers as affected by soil type and temperature. Soil Sci. Soc. Am. J. 74, 1635-1641.

Feng, Y. W., Yoshinaga, I., Shiratani, E., Hitomi, T., Hasebe H., 2005. Nutrient balance in a paddy field with a recycling irrigation system. Water Sci. Technol. 51 (3), $151-157$.

Feng, Y.W., Yoshinaga, I., Shiratani, E., Hitomi, T., Hasebe H., 2004. Characteristics and behavior of nutrients in a paddy field area equipped with recycling irrigation system. Agric. Water Manage. 68, 47-60.

Froelich, P. N., 1988. Kinetic control of dissolved phosphate in natural rivers and estuaries: A primer on the phosphate buffer mechanism. Limnol. Oceanogra. 33 (4), $649-668$

Haggard, B.E., Smith, D.R., Brye, K.R., 2007. Variations in stream water and sediment phosphorus among select Ozark catchments. J. Environ. Qual. 36, 1725-1734.

Hama, T., Aoki, T., Osuga, K., Sugiyama, S., Iwasaki, D., 2012. Nitrogen and phosphorus effluent loads from a paddy-field district adopting collective crop rotation. Water Sci. Technol. 66 (5), 1074-1080.

Hama, T., Nakamura, K., Kawashima, S., 2010. Effectiveness of cyclic irrigation in reducing suspended solids load from a paddy-field district. Agric. Water Manage. 97, $483-489$.

Hama, T., Nakamura, K., Kawashima, S., Kaneki, R., Mitsuno, T., 2011. Effects of cyclic irrigation on water and nitrogen mass balances in a paddy field. Ecol. Eng. 37, 
$1563-1566$.

Heathwaite, A.L., Dils, R.M., 2000. Characterising phosphorus loss in surface and subsurface hydrological pathways. Sci. Total Environ. 251/252, 523-538.

Hitomi, T., Yoshinaga, I., Feng, Y.W., Shiratani, E., 2006. Nitrogen removal function of recycling irrigation system. Water Sci. Technol. 53 (2), 101-109.

House, W.A., Denison, F.H., Armitage, P.D., 1995. Comparison of the uptake of inorganic phosphorus to a suspended and stream bed-sediment. Water Res. 29 (3), $767-779$.

Japan Meteorological Agency, 2010. Automated Meteorological Data Acquisition System (AMeDAS), URL http://www.jma.go.jp (accessed 1 July 2010).

Kaneki, R., 2003. Reduction of effluent nitrogen and phosphorus from paddy fields. Paddy Water Environ. 1, 133-138.

Kleinman, P.J.A., Sharpley, A.N., McDowell, R.W., Flaten, D.N., Buda, A.R., Tao, L., Bergstrom, L., Zhu, Q., 2011. Managing agricultural phosphorus for water quality protection: principles for progress. Plant Soil 349, 169-182.

Kröger, L., Holland, M.M., Moore, M.T., Cooper, C.M., 2008. Agricultural drainage ditches mitigate losses of phosphorus loads as a function of hydrological variability. J. Environ. Qual. 37, 107-113.

Krupa, M, Tate, K.W., van Kessel, C., Sarwar, N., Linquist, B.A., 2011. Water quality in rice-growing watersheds in a Mediterranean climate. Agric. Ecosyst. Environ. 144, 290-301.

McDowell, R.W., Wilcock, R.J., 2004. Particulate phosphorus transport within stream flow of an agricultural catchment. J. Environ. Qual. 33, 2111-2121. 
Murphy, J., Riley, J.P., 1962. A modified single solution method for the determination of phosphorus in natural waters. Anal. Chem. Acta 12, 31-36.

Penman, H.L., 1948. Natural evaporation from open water, bare soil and grass. Proc. Royal Soc. Lond. A 193, 120-145.

Portielje, J., Van der Molen, D., 1999. Relationships between eutrophication variables: from nutrient loading to transparency. Hydrobiologia 408/409, 375-387.

Reddy, K.R., Flaig, E.G., Graetz, D.A., 1996. Phosphorus storage capacity of uplands, wetlands and streams of the Lake Okeechobee Watershed, Florida. Agric. Ecosyst. Environ. 59, 203-216.

Richards, R.P., Baker, D.B., Crumrine, J.P., Kramer, J.W., Ewing, D.E., Merryfield, B.J., 2008. Thirty-year trends in suspended sediment in seven Lake Erie tributaries. J. Environ. Qual. 37, 1894-1908.

Sakuratani, T., Horie, T., 1985. Studies on evapotranspiration from crops, 1: On seasonal changes, vertical differences and the simplified methods of estimate in evapotranspiration of paddy rice. J. Agric. Meteorol. 41 (1), 45-55 (in Japanese).

Sallade, Y.E., Sims, J.T., 1997. Phosphorus transformation in the sediments of Delaware's agricultural drainageways: I. Phosphorus forms and sorption. J. Environ. Qual. 26, 1571-1579.

Sharpley, A.N., 1995. Soil phosphorus dynamics: agronomic and environmental impacts. Ecol. Eng. 5, 261-279.

Shiratani, E., Yoshinaga, I., Feng, Y. W., Hasebe, H. 2004. Scenario analysis for reduction of effluent load from an agricultural area by recycling the run-off water. Water Sci. Technol. 49 (3), 55-62. 
Simard, R.R., Beauchemin, S., Haygarth, P.M., 2000. Potential for preferential pathways of phosphorus transport. J. Environ. Qual. 29, 97-105.

Smith, D.R., Haggard, B.E., Warnemuende, E.A., Huang, C., 2005. Sediment phosphorus dynamics for three tile fed drainage ditches in Northeast Indiana. Agric. Water Manage. 71, 19-32.

Smith, D.R., Warnemuende, E.A., Haggard, B.E., Huang, C., 2006. Dredging of drainage ditches increases short-term transport of soluble phosphorus. J. Environ. Qual. 35, 611-616.

Takeda, I., Fukushima, A. 2006. Long-term changes in pollutant load outflows and purification function in a paddy field watershed using a cyclic irrigation system. Water Res. 40, 569-578.

Takeda, I., Fukushima, A., 2004. Phosphorus purification in a paddy field watershed using a circular irrigation system and the role of iron compounds. Water Res. 38, 4065-4074.

Takeda, I., Fukushima, A., Tanaka, R., 1997. Non-point pollutant reduction in a paddy-field watershed using a cyclic irrigation system. Water Res. 31, 2685-2692. Uusitalo, R., Yli-Halla, M., Turtola, E., 2000. Suspended soil as a source of potentially bioavailable phosphorus in surface runoff waters from clay soils. Water Res. 34 (9), $2477-2482$.

Yoshinaga, I., Asa, M., Hitomi, T., Hamada, K., Shiratani, E., 2007. Runoff nitrogen from a large sized paddy field during a crop period. Agric. Water Manage. 87, 217-222.

Zulu, G., Toyota, M., Misawa, S., 1996. Characteristics of water reuse and its effects on 
paddy irrigation system water balance and the riceland ecosystem. Agric. Water Manage. 31, 269-283. 


\section{Figures}
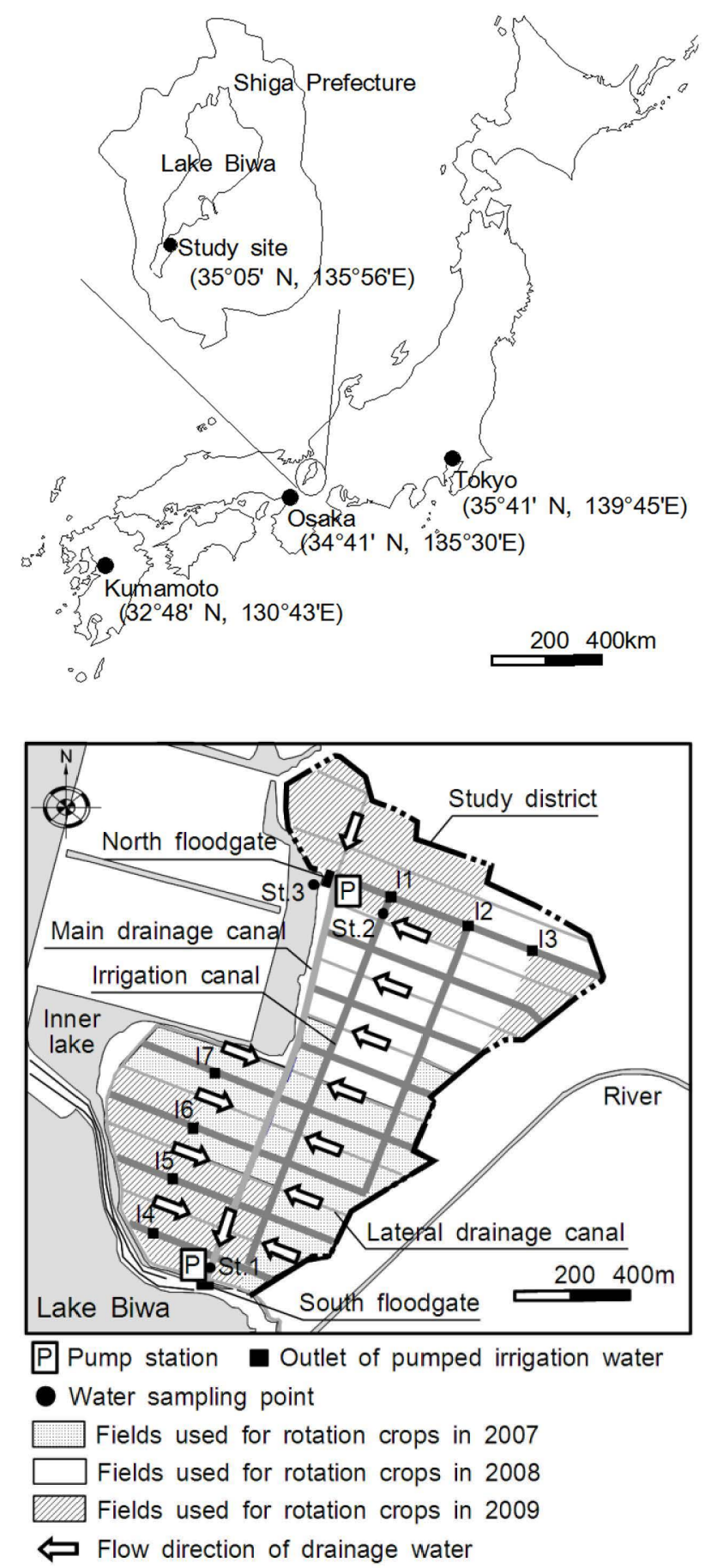

Fig. 1 - (a) Location of the study site. (b) Layout of paddy fields, water source, pump stations, and irrigation and drainage canals in the study district. 


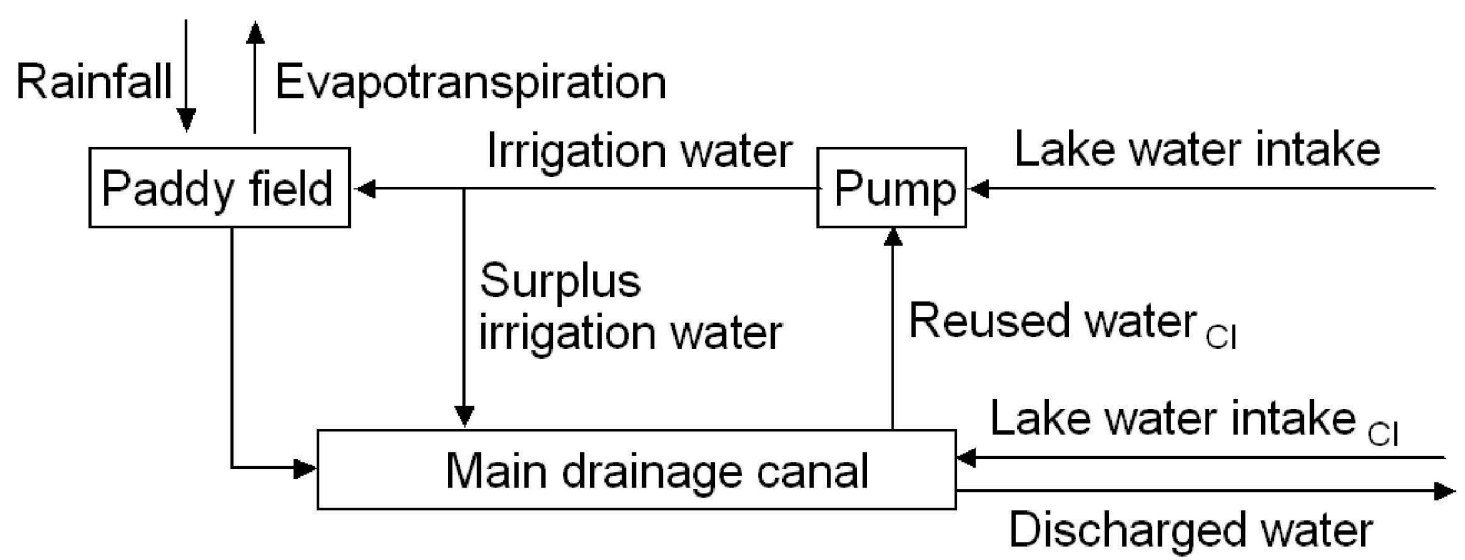

Fig. 2 - Conceptual diagram of water flow under cyclic irrigation (CI) in the paddy-field district. 


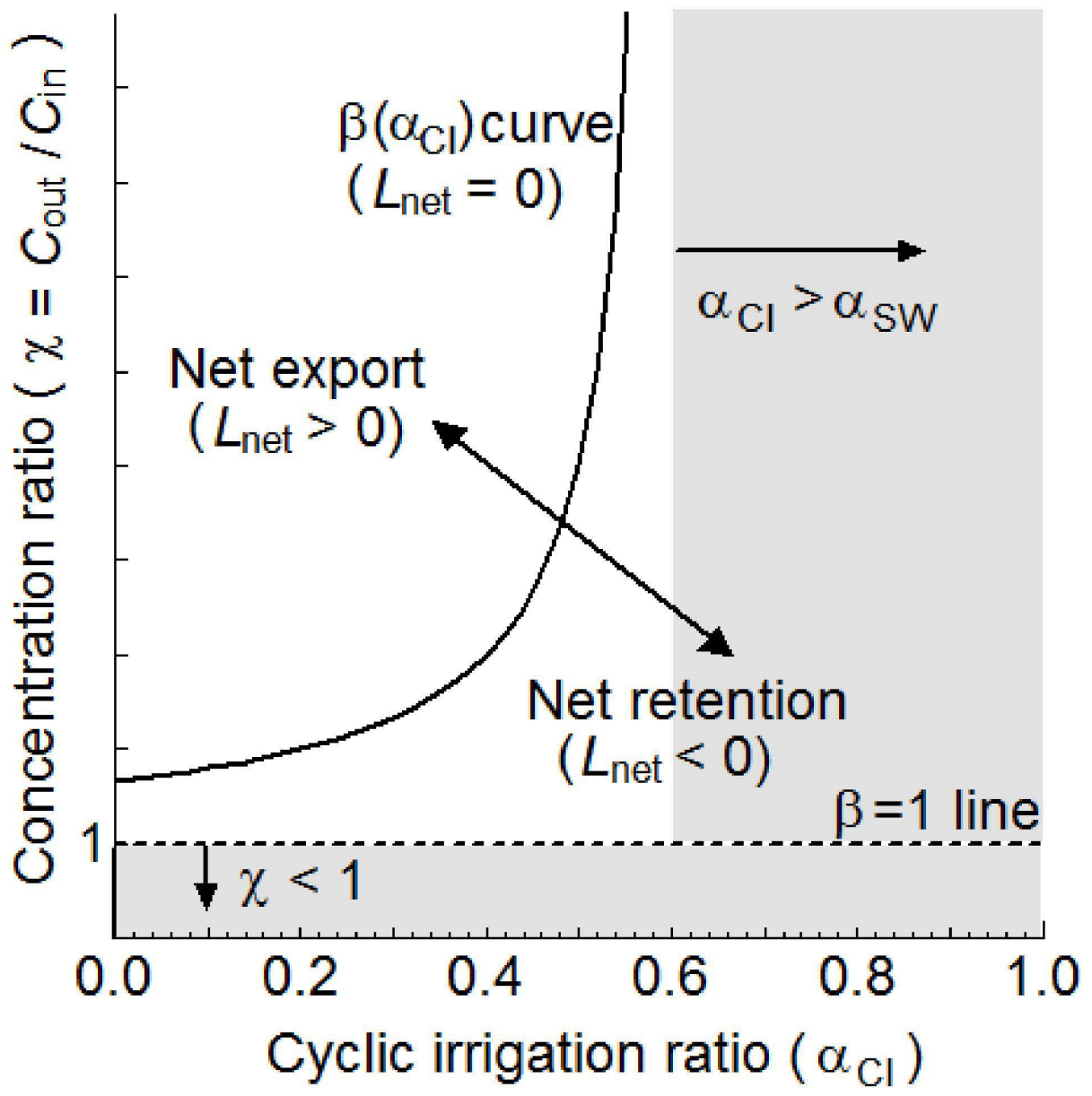

Fig. 3 - Neutral effect curve for the net effluent load at a given surplus irrigation ratio. The colored area represents the conditions under which irrigation has a purification effect on the net phosphorus effluent load for any cyclic irrigation ratio or concentration ratio. 

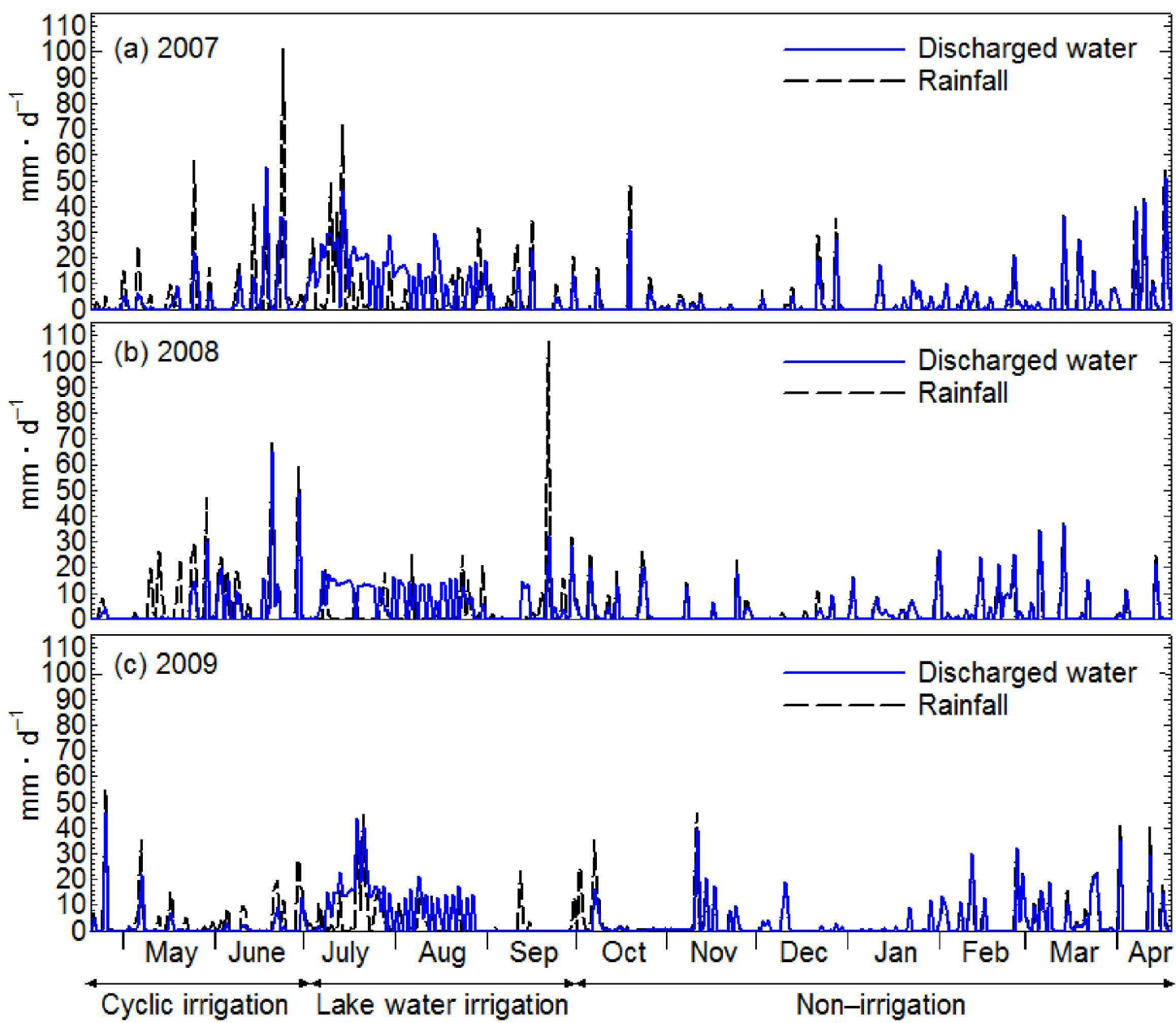

Fig. 4 - Daily variations in discharged water and rainfall, in (a) 2007-2008, in (b) 2008-2009, and in (c) 2009-2010. 


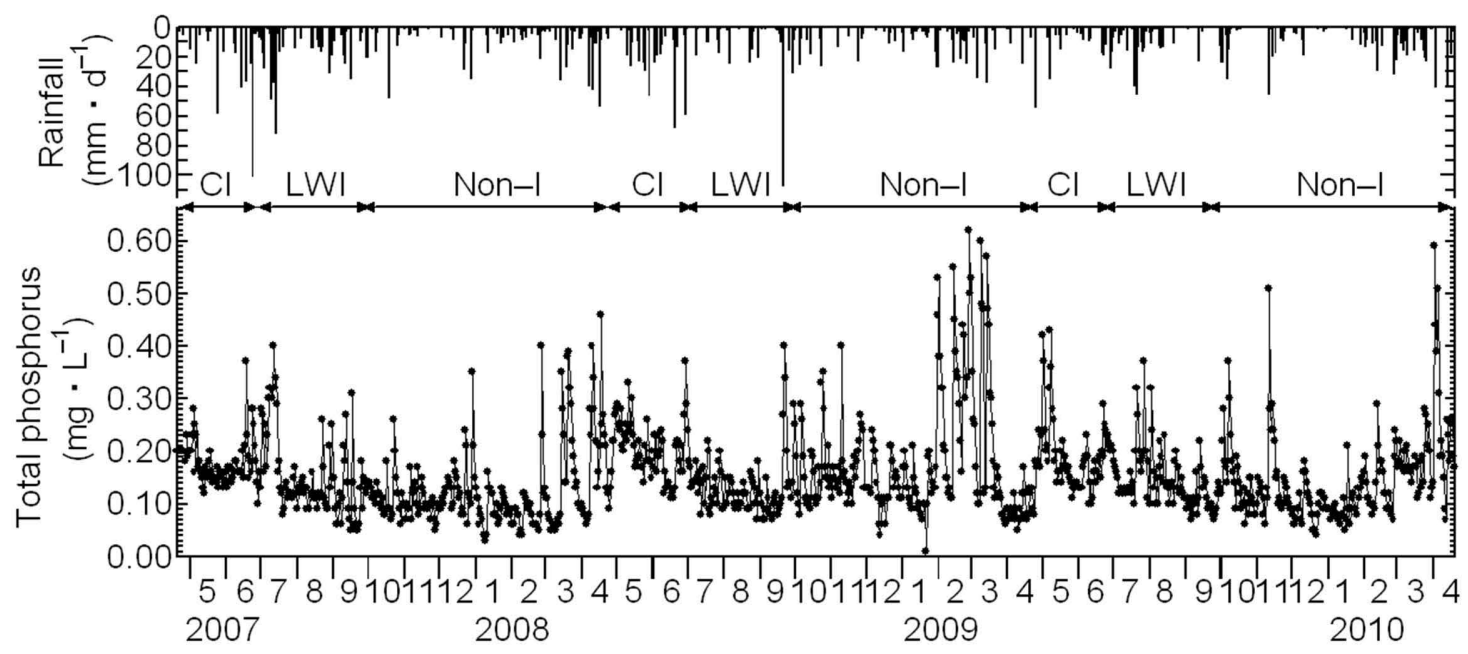

Fig. 5 - Daily variations in total phosphorus in drainage water and rainfall, 2007-2010. CI, cyclic irrigation; LWI, lake water irrigation; Non-I, non-irrigation. 


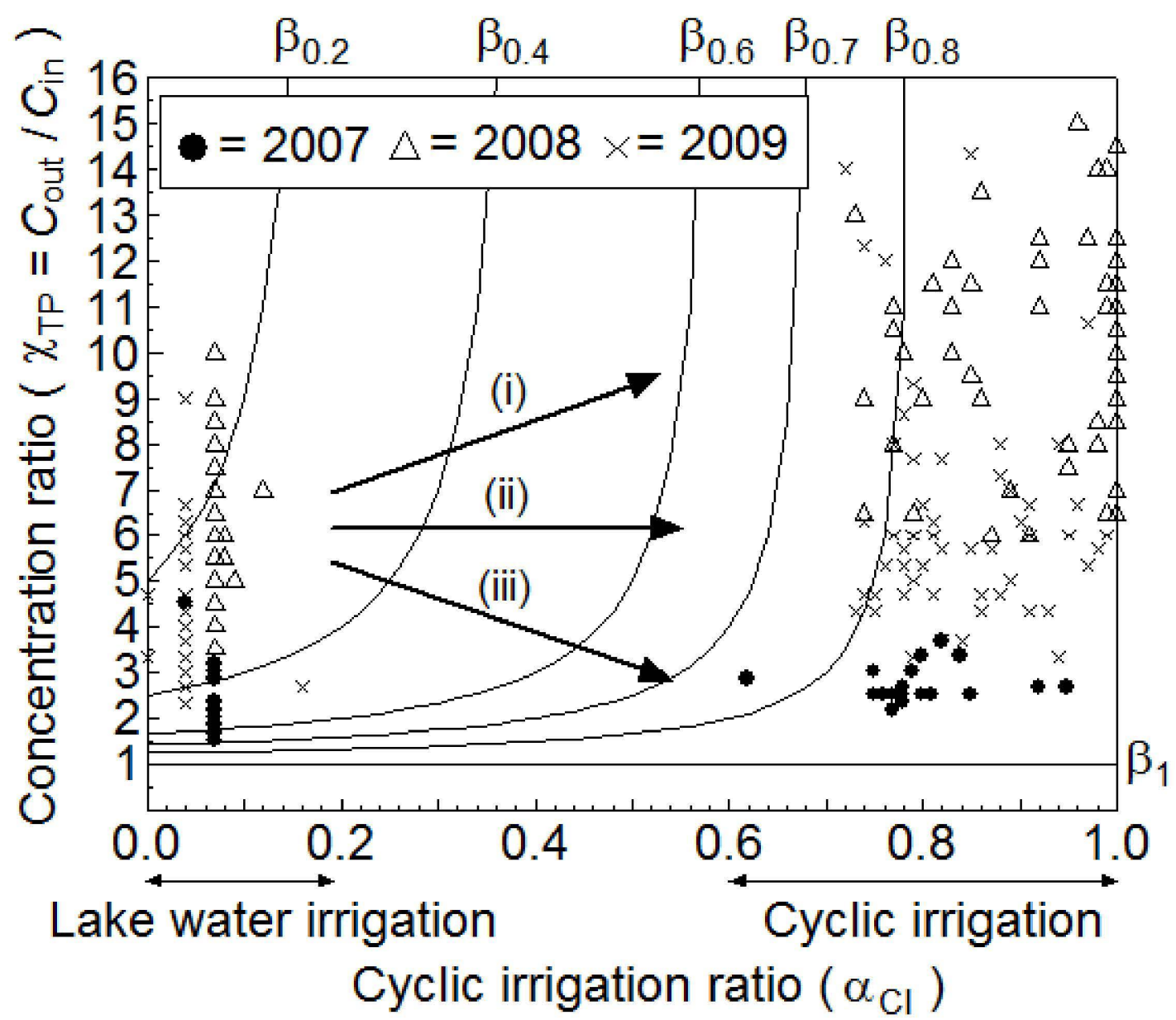

Fig. 6 - Relationship between the cyclic irrigation ratio and the concentration ratio for various $\beta$ curves. Subscripts of $\beta$ represent the surplus irrigation ratio. As $\alpha_{\text {CI }}$ increases, (i) $\chi_{\text {TP }}$ increases, (ii) $\chi_{\text {TP }}$ does not change, and (iii) $\chi_{\text {TP }}$ decreases. 


\section{Tables}

Table 1 - Irrigation schedule for the study district.

\begin{tabular}{|c|c|c|c|}
\hline Irrigation schedule & 2007 & 2008 & 2009 \\
\hline Start of irrigation & April 25 & April 26 & April 24 \\
\hline Cyclic irrigation period & April 25-June 23 & April 26-June 24 & April 24-June 25 \\
\hline $\begin{array}{l}\text { Mid-summer drainage } \\
\text { season }\end{array}$ & June 24-July 5 & June 25-July 6 & June 26-July 9 \\
\hline $\begin{array}{l}\text { Lake water irrigation } \\
\text { period }\end{array}$ & July 6-August 28 & July 7-August 26 & July $10-$ September 2 \\
\hline End of irrigation & August 28 & August 26 & September 2 \\
\hline
\end{tabular}


Table 2 - Water balance (mm) for the study district during the irrigation periods.

\begin{tabular}{|c|c|c|c|c|c|c|}
\hline \multirow{2}{*}{ Year } & \multirow{2}{*}{ Period $^{\mathrm{a}}$} & \multicolumn{2}{|c|}{ Inflow } & \multicolumn{2}{|l|}{ Outflow } & \multirow{2}{*}{$\begin{array}{l}\text { Irrigation } \\
\text { water } \\
\text { (Pumped } \\
\text { water) }\end{array}$} \\
\hline & & $\begin{array}{l}\text { Rain } \\
\text { fall }\end{array}$ & $\begin{array}{l}\text { Lake water } \\
\text { intake }\end{array}$ & $\begin{array}{l}\text { Evapotransp } \\
\text { iration }\end{array}$ & $\begin{array}{l}\text { Discharged } \\
\text { water }\end{array}$ & \\
\hline \multirow[t]{4}{*}{2007} & $\begin{array}{l}\text { Cyclic } \\
\text { irrigation }\end{array}$ & 405 & 173 & 277 & 277 & 965 \\
\hline & $\begin{array}{l}\text { Lake } \\
\text { water } \\
\text { irrigation }\end{array}$ & 565 & 677 & 376 & 919 & 727 \\
\hline & $\begin{array}{l}\text { Non-irriga } \\
\text { tion }\end{array}$ & 663 & - & 59 & 558 & - \\
\hline & Total & 1633 & 850 & 712 & 1754 & 1692 \\
\hline \multirow[t]{4}{*}{2008} & $\begin{array}{l}\text { Cyclic } \\
\text { irrigation }\end{array}$ & 481 & 100 & 277 & 285 & 964 \\
\hline & $\begin{array}{l}\text { Lake } \\
\text { water } \\
\text { irrigation }\end{array}$ & 347 & 648 & 442 & 610 & 644 \\
\hline & $\begin{array}{l}\text { Non-irriga } \\
\text { tion }\end{array}$ & 600 & - & 65 & 527 & - \\
\hline & Total & 1428 & 748 & 784 & 1422 & 1608 \\
\hline \multirow[t]{4}{*}{2009} & $\begin{array}{l}\text { Cyclic } \\
\text { irrigation }\end{array}$ & 280 & 168 & 287 & 124 & 1046 \\
\hline & $\begin{array}{l}\text { Lake } \\
\text { water } \\
\text { irrigation }\end{array}$ & 331 & 605 & 365 & 583 & 618 \\
\hline & $\begin{array}{l}\text { Non-irriga } \\
\text { tion }\end{array}$ & 721 & - & 61 & 622 & - \\
\hline & Total & 1332 & 773 & 713 & 1329 & 1664 \\
\hline
\end{tabular}

${ }^{a}$ Cyclic irrigation $=$ April 20-June 30 (72 days); lake water irrigation $=$ July 1-September 30 (92 days); non-irrigation $=$ October 1 -April 19 (201 or 202 days). 
Table 3 - Mean total phosphorus concentrations in drainage water sampled daily during the three irrigation management phases, 2007-2009.

\begin{tabular}{|c|c|c|c|c|c|c|}
\hline \multirow{2}{*}{ Period } & \multicolumn{2}{|l|}{2007} & \multicolumn{2}{|l|}{2008} & \multicolumn{2}{|l|}{2009} \\
\hline & $\mathrm{TP}^{\mathrm{a}}\left(\mathrm{mg} \cdot \mathrm{L}^{-1}\right)$ & $n$ & $\mathrm{TP}\left(\mathrm{mg} \cdot \mathrm{L}^{-1}\right)$ & $n$ & $\mathrm{TP}\left(\mathrm{mg} \cdot \mathrm{L}^{-1}\right)$ & $n$ \\
\hline $\begin{array}{l}\text { Cyclic } \\
\text { irrigation }\end{array}$ & $0.18 \pm 0.04^{\mathrm{y}}$ & 61 & $0.20 \pm 0.05^{\mathrm{xy}}$ & 61 & $0.19 \pm 0.07^{\mathrm{xy}}$ & 64 \\
\hline $\begin{array}{l}\text { Lake water } \\
\text { irrigation }\end{array}$ & $0.16 \pm 0.08^{\mathrm{z}}$ & 55 & $0.13 \pm 0.03^{\mathrm{xz}}$ & 52 & $0.16 \pm 0.06^{\mathrm{x}}$ & 56 \\
\hline $\begin{array}{l}\text { Non-irrigatio } \\
\mathrm{n}\end{array}$ & $0.12 \pm 0.07^{\mathrm{yz}}$ & 241 & $0.17 \pm 0.11^{\mathrm{yz}}$ & 240 & $0.14 \pm 0.08^{\mathrm{y}}$ & 230 \\
\hline
\end{tabular}

${ }^{\mathrm{a}} \mathrm{TP}$, total phosphorus. Statistically significant differences of $p<0.05$ (Tukey-test) are indicated by lower-case letters respectively (x, cyclic irrigation vs. lake water irrigation; $y$, cyclic irrigation vs. non-irrigation; $z$, lake water irrigation vs. non-irrigation). 
Table 4 - Mean concentrations of total phosphorus and phosphorus as phosphate in drainage water and irrigation water sampled weekly during the cyclic irrigation and lake water irrigation periods, 2007-2009.

\begin{tabular}{|c|c|c|c|c|c|}
\hline \multirow[b]{2}{*}{ Year } & \multirow[b]{2}{*}{ Period } & \multicolumn{2}{|l|}{ Drainage water } & \multicolumn{2}{|l|}{ Irrigation water } \\
\hline & & $\mathrm{TP}^{\mathrm{a}} \quad\left(\mathrm{mg} \cdot \mathrm{L}^{-1}\right)$ & $\begin{array}{l}\mathrm{PO}_{4}-\mathrm{P}^{\mathrm{b}} \\
\left(\mathrm{mg} \cdot \mathrm{L}^{-1}\right)\end{array}$ & $\mathrm{TP} \quad\left(\mathrm{mg} \cdot \mathrm{L}^{-1}\right)$ & $\begin{array}{l}\mathrm{PO}_{4}-\mathrm{P} \\
\left(\mathrm{mg} \cdot \mathrm{L}^{-1}\right)\end{array}$ \\
\hline \multirow[t]{2}{*}{2007} & $\begin{array}{l}\text { Cyclic } \\
\text { irrigation } \\
(n=18)\end{array}$ & $0.18 \pm 0.06^{\mathrm{xw}}$ & $0.02 \pm 0.01$ & $0.27 \pm 0.10^{\mathrm{xW}}$ & $0.02 \pm 0.01^{\mathrm{x}}$ \\
\hline & $\begin{array}{l}\text { Lake } \\
\text { water } \\
\text { irrigation } \\
(n=5)\end{array}$ & $0.12 \pm 0.02^{\mathrm{xw}}$ & $0.02 \pm 0.01^{\mathrm{w}}$ & $0.05 \pm 0.02^{\mathrm{xw}}$ & $0.01 \pm 0.00^{\mathrm{xw}}$ \\
\hline \multirow[t]{2}{*}{2008} & $\begin{array}{l}\text { Cyclic } \\
\text { irrigation } \\
(n=11)\end{array}$ & $0.21 \pm 0.07^{\mathrm{xw}}$ & $0.05 \pm 0.02^{\mathrm{x}}$ & $0.30 \pm 0.06^{\mathrm{xW}}$ & $0.06 \pm 0.02^{\mathrm{x}}$ \\
\hline & $\begin{array}{l}\text { Lake } \\
\text { water } \\
\text { irrigation } \\
(n=5)\end{array}$ & $0.14 \pm 0.04^{\mathrm{xw}}$ & $0.03 \pm 0.00^{\mathrm{xw}}$ & $0.02 \pm 0.01^{\mathrm{xw}}$ & $0.01 \pm 0.00^{\mathrm{xw}}$ \\
\hline \multirow[t]{2}{*}{2009} & $\begin{array}{l}\text { Cyclic } \\
\text { irrigation } \\
(n=8)\end{array}$ & $0.25 \pm 0.11$ & $0.06 \pm 0.04$ & $0.34 \pm 0.12^{\mathrm{x}}$ & $0.08 \pm 0.03^{x}$ \\
\hline & $\begin{array}{l}\text { Lake } \\
\text { water } \\
\text { irrigation } \\
(n=5)\end{array}$ & $0.14 \pm 0.07^{\mathrm{w}}$ & $0.03 \pm 0.04$ & $0.03 \pm 0.01^{\mathrm{xW}}$ & $0.01 \pm 0.01^{\mathrm{x}}$ \\
\hline
\end{tabular}


Table 5 - Inputs and exports of total phosphorus during each irrigation management phase, 2007-2009.

\begin{tabular}{|c|c|c|c|c|c|c|c|c|c|}
\hline \multirow{3}{*}{ Year } & \multirow{3}{*}{ Period $^{\mathrm{a}}$} & \multicolumn{4}{|l|}{ Inputs } & \multicolumn{4}{|l|}{ Exports } \\
\hline & & \multicolumn{2}{|l|}{ Rainfall } & \multicolumn{2}{|c|}{ Lake water intake } & \multicolumn{2}{|c|}{ Discharged water } & \multicolumn{2}{|l|}{$\mathrm{Net}^{\mathrm{b}}$} \\
\hline & & $\left(\mathrm{kg} \cdot \mathrm{ha}^{-1}\right)^{\mathrm{c}}$ & $\left(g \cdot h a^{-1} \cdot d^{-1}\right)^{d}$ & $\left(\mathrm{~kg} \cdot \mathrm{ha}^{-1}\right)$ & $\left(\mathrm{g} \cdot \mathrm{ha}^{-1} \cdot \mathrm{d}^{-1}\right)$ & $\left(\mathrm{kg} \cdot \mathrm{ha}^{-1}\right)$ & $\left(\mathrm{g} \cdot h \mathrm{~h}^{-1} \cdot \mathrm{d}^{-1}\right)$ & $\left(\mathrm{kg} \cdot \mathrm{ha}^{-1}\right)$ & $\left(\mathrm{g} \cdot \mathrm{ha}^{-1} \cdot \mathrm{d}^{-1}\right)$ \\
\hline \multirow[t]{4}{*}{2007} & $\begin{array}{l}\text { Cyclic } \\
\text { irrigation }\end{array}$ & 0.08 & 1.0 & 0.20 & 2.8 & 0.63 & 8.8 & 0.35 & 5.0 \\
\hline & $\begin{array}{l}\text { Lake-water } \\
\text { irrigation }\end{array}$ & 0.10 & 1.1 & 0.39 & 4.3 & 1.66 & 18.0 & 1.17 & 12.6 \\
\hline & Non-irrigation & 0.12 & 0.6 & 0.00 & 0.0 & 0.84 & 4.1 & 0.72 & 3.5 \\
\hline & Total & 0.30 & 0.8 & 0.59 & 1.6 & 3.13 & 8.5 & 2.24 & 6.1 \\
\hline \multirow[t]{4}{*}{2008} & $\begin{array}{l}\text { Cyclic } \\
\text { irrigation }\end{array}$ & 0.09 & 1.2 & 0.07 & 1.0 & 0.58 & 8.0 & 0.42 & 5.8 \\
\hline & $\begin{array}{l}\text { Lake-water } \\
\text { irrigation }\end{array}$ & 0.06 & 0.7 & 0.15 & 1.7 & 0.82 & 8.9 & 0.61 & 6.5 \\
\hline & Non-irrigation & 0.11 & 0.6 & 0.00 & 0.0 & 1.28 & 6.3 & 1.17 & 5.7 \\
\hline & Total & 0.26 & 0.7 & 0.22 & 0.6 & 2.68 & 7.3 & 2.20 & 6.0 \\
\hline \multirow[t]{4}{*}{2009} & $\begin{array}{l}\text { Cyclic } \\
\text { irrigation }\end{array}$ & 0.05 & 0.7 & 0.09 & 1.2 & 0.27 & 3.7 & 0.13 & 1.8 \\
\hline & $\begin{array}{l}\text { Lake-water } \\
\text { irrigation }\end{array}$ & 0.06 & 0.7 & 0.17 & 1.9 & 0.93 & 10.1 & 0.70 & 7.5 \\
\hline & Non-irrigation & 0.13 & 0.7 & 0.00 & 0.0 & 1.42 & 7.1 & 1.29 & 6.4 \\
\hline & Total & 0.24 & 0.7 & 0.26 & 0.7 & 2.62 & 7.2 & 2.12 & 5.8 \\
\hline
\end{tabular}

${ }^{\mathrm{a}}$ Cyclic irrigation $=$ April 20-June 30 (72 days); lake-water irrigation $=$ July 1-September 30 (92 days); non-irrigation $=$ October 1-April 19 (201 or 202 days). ${ }^{\text {b }}$ Net export = expert of "discharged water" minus inputs of "rainfall" and "lake water intake." ${ }^{\mathrm{c}}$ Period integrated value. ${ }^{\mathrm{d}}$ Period average rate. 